\title{
Pesticide residues in agricultural crops (2013)
}

\section{Pozostałości środków ochrony roślin w płodach rolnych (rok 2013)}

\author{
Anna Nowacka ${ }^{1 *}$, Bogusław Gnusowski ${ }^{1}$, Stanisław Walorczyk ${ }^{1}$, Dariusz Drożdżyński ${ }^{1}$, Michał Raczkowski ${ }^{1}$, \\ Agnieszka Hołodyńska-Kulas ${ }^{1}$, Dorota Frąckowiak ${ }^{1}$, Andrzej Ziółkowski ${ }^{1}$, Monika Przewoźniak ${ }^{1}$, \\ Urszula Rzeszutko ${ }^{2}$, Izabela Domańska², Klaudia Pszczolińska², Bożena Łozowicka ${ }^{3}$, Piotr Kaczyński ${ }^{3}$, \\ Ewa Rutkowska ${ }^{3}$, Magdalena Jankowska $^{3}$, Izabela Hrynko ${ }^{3}$, Ewa Szpyrka ${ }^{4}$, Julian Rupar ${ }^{4}$, Aneta Matyaszek ${ }^{4}$, \\ Anna Kurdziel ${ }^{4}$, Magdalena Podbielska ${ }^{4}$, Magdalena Słowik-Borowiec ${ }^{4}$, Marta Szponik ${ }^{5}$
}

\section{Summary}

In 2013, the Institute of Plant Protection - National Research Institute under the official control of pesticide residues in primary production analysed 1304 samples of agricultural products collected from production sites all over the country. The study included 38 products and 274 pesticides and their metabolites. Most of the samples tested were vegetables and fruits (88.9\%), while the remaining percentage of the samples was comprised mainly of rape and cereal grains, and sugar beets. Overall, $98.0 \%$ of the analysed samples were compliant with the legal limits, while $2.0 \%$ of the samples exceeded the European Union maximum residue levels (EU MRLs). The residues indicating the illegal use of plant protection products were detected in $6.5 \%$ of the samples. A total of 60 compounds were found in $32.4 \%$ of the samples. Fungicide residues were the most frequently occurring residue type (66.4\%). Dithiocarbamates, carbendazim, boscalid were the most commonly detected. Pesticide residues were found in $46.5 \%$ of fruit samples, mostly in gooseberries (78.6\%), strawberries (69.7\%), apples (56.7\%) and in $24.1 \%$ of vegetable samples, primarily in carrots $(59.5 \%)$ and tomatoes (46.4\%). Pesticide residues were also present in samples of rapeseed (27.3\%) and sugar beet root (18.2\%).

Key words: pesticide residues; fruit; vegetables; cereals; rape seeds; sugar beet roots; MRLs exceedances; unauthorized substances

\section{Streszczenie}

W 2013 roku Instytut Ochrony Roślin - Państwowy Instytut Badawczy w ramach urzędowej kontroli pozostałości środków ochrony roślin na etapie produkcji pierwotnej przeanalizował 1304 próbki pobrane z gospodarstw produkcyjnych na terenie całego kraju. Badaniami objęto 38 produktów i 274 substancje czynne i ich metabolity. Większość badanych próbek stanowiły warzywa i owoce (88,9\%), zaś pozostałą część przeważnie próbki ziarna zbóż i rzepaku oraz buraków cukrowych. Ogółem, 98,0\% kontrolowanych próbek płodów rolnych spełniało wymagania dotyczące najwyższych dopuszczalnych pozostałości pestycydów, natomiast w 2,0\% wykryto przekroczenia najwyższych dopuszczalnych poziomów pozostałości (NDP). Pozostałości wskazujące na stosowanie środków niedopuszczonych do ochrony stwierdzono w 6,5\% próbek. Łącznie wykryto 60 związków w 32,4\% badanych próbek. Pozostałości fungicydów były najpowszechniejsze (66,4\%). Najczęściej wykrywano ditiokarbaminiany, karbendazym i boskalid. Pozostałości pestycydów zawierało 46,5\% próbek owoców, głównie agrest (78,6\%), truskawki $(69,7 \%)$, jabłka (56,7\%) i 24,1\% próbek warzyw, zwłaszcza marchew $(59,5 \%)$ i pomidory $(46,4 \%)$. Ponadto były obecne w próbkach nasion rzepaku $(27,3 \%)$ i korzeniach buraka cukrowego $(18,2 \%)$.

Słowa kluczowe: pozostałości pestycydów; owoce; warzywa; zboża; rzepak; burak cukrowy; przekroczenia NDP; substancje niedozwolone

\footnotetext{
${ }^{1}$ Instytut Ochrony Roślin - Państwowy Instytut Badawczy (IOR - PIB), Władysława Węgorka 20, 60-318 Poznań

${ }^{2}$ Oddział IOR - PIB, Gliwicka 29, 44-153 Sośnicowice

${ }^{3}$ IOR - PIB, Terenowa Stacja Doświadczalna, Chełmońskiego 22, 15-195 Białystok

${ }^{4}$ IOR - PIB, Terenowa Stacja Doświadczalna, Langiewicza 28, 35-101 Rzeszów

${ }^{5}$ IOR - PIB, Terenowa Stacja Doświadczalna, Milicka 21, 55-100 Trzebnica

*corresponding author: a.nowacka@iorpib.poznan.pl
} 


\section{Wstęp / Introduction}

Ochrona zdrowia ludzi i środowiska przed ewentualnymi niepożądanymi skutkami stosowania środków ochrony roślin (ś.o.r.) w rolnictwie jest ważnym zadaniem wszystkich państw członkowskich Unii Europejskiej (UE). Zapewnienie bezpieczeństwa zdrowotnego konsumentów w tym zakresie opiera się na szeroko zakrojonych badaniach pozostałości ś.o.r. w żywności i paszach na etapie ich produkcji i sprzedaży przeprowadzanych w ramach urzędowych kontroli. Badania mają ścisłe umocowania prawne i są nadzorowane przez Komisję Europejską. Obowiązek prowadzenia takich badań wynika zarówno $\mathrm{z}$ prawa krajowego, w szczególności ustawy $\mathrm{z}$ dnia 18 grudnia 2003 r. o ochronie roślin (Ustawa 2004) i ustawy z dnia 8 marca 2013 r. o środkach ochrony roślin (Ustawa 2013), jak i przepisów Unii Europejskiej, w szczególności rozporządzenia Parlamentu Europejskiego i Rady (WE) nr 1107/2009 z dnia 21 października 2009 r. dotyczącego wprowadzania do obrotu środków ochrony roślin i uchylającego dyrektywy Rady 79/117/EWG i 91/414/EWG (Rozporządzenie 2009), dyrektywy Parlamentu Europejskiego i Rady 2009/128/WE z dnia 21 października 2009 r. ustanawiającej ramy wspólnotowego działania na rzecz zrównoważonego stosowania pestycydów (Dyrektywa 2009), rozporządzenia (WE) nr 396/2005 Parlamentu Europejskiego i Rady z dnia 23 lutego 2005 r. w sprawie najwyższych dopuszczalnych poziomów pozostałości pestycydów w żywności i paszy pochodzenia roślinnego i zwierzęcego oraz na ich powierzchni, zmieniające dyrektywę Rady 91/414/EWG (Rozporządzenie 2005).

Urzędowe badania pozostałości ś.o.r. w krajowej produkcji pierwotnej mają na celu ocenę prawidłowości stosowania ś.o.r. Ich celem jest sprawdzenie przestrzegania przez producentów płodów rolnych zapisów: art. 55 rozporządzenia odnośnie wprowadzania do obrotu środków ochrony roślin (Rozporządzenie 2009); art. 46 ustawy o środkach ochrony roślin (Ustawa 2013) oraz rozporządzenia w sprawie najwyższych dopuszczalnych poziomów pozostałości pestycydów w żywności i paszy pochodzenia roślinnego i zwierzęcego oraz na ich powierzchni (Rozporządzenie 2005). Informacje o wszystkich wykrytych przypadkach zastosowania środków niedozwolonych i przekroczeniach najwyższych dopuszczalnych poziomów pozostałości pestycydów są sygnalizowane w formie powiadomień RASFF (Rapid Alert System for Food and Feed), zgodnie z prawodawstwem unijnym - procedurą systemu wczesnego ostrzegania o niebezpiecznej żywności i paszach (Rozporządzenie 2002) oraz rozporządzeniem Komisji UE ustanawiającym środki wykonawcze dla systemu wczesnego ostrzegania o niebezpiecznych produktach żywnościowych i środkach żywienia zwierząt (Rozporządzenie 2011), jak i krajowym - ustawą o bezpieczeństwie żywności i żywienia (Ustawa 2010). Są one podstawą stosowania sankcji wobec naruszających postanowienia wyżej wymienionego prawa. Ma to na celu zmobilizowanie rolników do przestrzegania zasad dobrej praktyki rolniczej. Badania pozwalają nie tylko na prowadzenie systematycznego nadzoru nad stosowaniem ś.o.r., ale także na diagnozowanie problemów pojawia- jących się w tym obszarze działalności rolniczej. Ponadto, są one dla Ministerstwa Rolnictwa i Rozwoju Wsi cennym źródłem aktualnej wiedzy o zakresach i poziomach występujących skażeń w płodach rolnych, a także pośrednio informują o skuteczności przepisów regulujących warunki i sposoby stosowania ś.o.r. w praktyce rolniczej. Badania umożliwiają ponadto szacowanie długo- i krótkoterminowego narażenia ludzi na pozostałości pestycydów, co pozwala na ocenę ryzyka zdrowotnego związanego $\mathrm{z}$ ich pobraniem $\mathrm{z}$ żywnością.

Laboratoria Instytutu Ochrony Roślin - Państwowego Instytutu Badawczego (IOR - PIB) oznaczają pozostałości ś.o.r. w płodach rolnych już od 1971 roku, przy czym od roku 1996 wspólnie z Państwową Inspekcją Ochrony Roślin i Nasiennictwa (PIORiN), w tym od roku 2006 na mocy programów wieloletnich, realizowanych przez IOR PIB i nadzorowanych przez Ministra Rolnictwa i Rozwoju Wsi.

Przedstawione w pracy badania zostały przeprowadzone w ramach urzędowej kontroli produkcji pierwotnej, prowadzonej przez IOR - PIB w ramach programu wieloletniego na lata 2011-2015 (Uchwała 2011). Ich celem była ocena pozostałości ś.o.r. w płodach rolnych, pochodzących $\mathrm{w}$ głównej mierze $\mathrm{z}$ upraw intensywnie chronionych (warzywa, owoce), wyprodukowanych w sezonie wegetacyjnym 2013. Chodziło o stwierdzenie, w jakich stężeniach i jakiego rodzaju pozostałości ś.o.r. występują w krajowych produktach i czy mieszczą się one w dopuszczalnych zakresach. Badania miały na celu rozpoznanie, w jakim stopniu polscy rolnicy przestrzegają przepisów w zakresie ochrony roślin, zdiagnozowanie potencjalnych zagrożeń i umożliwienie PIORiN podjęcia stosownych działań w przypadku wykrycia nieprawidłowości w stosowaniu ś.o.r.

\section{Materiały i metody / Materials and methods}

W roku 2013, w trakcie urzędowej kontroli zbadano na zawartość pozostałości ś.o.r. 1304 próbki płodów rolnych, pochodzących z krajowych gospodarstw rolnych zajmujących się uprawą warzyw, owoców, zbóż, roślin oleistych i cukrodajnych. Program kontroli został opracowany przez Główny Inspektorat Ochrony Roślin i Nasiennictwa (GIORiN), zaś za pobór próbek w poszczególnych województwach były odpowiedzialne Wojewódzkie Inspektoraty Ochrony Roślin i Nasiennictwa (WIORiN). Próbki pobierano w sposób losowy, zgodny $\mathrm{z}$ wymaganiami określonymi dla tego rodzaju badań (Rozporządzenie 2007). Próbki analizowano w laboratoriach IOR - PIB w Poznaniu, Białymstoku, Rzeszowie, Sośnicowicach i Trzebnicy. Wyniki badań były systematycznie przesyłane właściwym inspektoratom wojewódzkim, przy czym o wszystkich wykrytych nieprawidłowościach w stosowaniu ś.o.r. były one również informowane $w$ drodze powiadomień alarmowych, obowiązujących w unijnym systemie wczesnego ostrzegania o niebezpiecznej żywności i paszach - RASFF.

Program badań obejmował 38 rodzajów płodów rolnych oraz 274 substancje czynne ś.o.r. i/lub ich pochodne. Spośród poszukiwanych związków 128 należało do grupy 
insektycydów i akarycydów, 90 do fungicydów, a 56 do herbicydów i regulatorów wzrostu. Wśród badanych próbek największy odsetek stanowiły warzywa i owoce $88,9 \%$, na który złożyło się 626 próbek warzyw (22 gatunki) oraz 533 próbki owoców (11 gatunków), natomiast pozostały niewielki odsetek $(11,1 \%)$ próbki: jęczmienia
$(1,6 \%)$, kukurydzy $(2,6 \%)$, nasion rzepaku $(5,1 \%)$, buraka cukrowego $(1,7 \%)$ i suchych nasion grochu $(0,2 \%)$. Jabłka, maliny, porzeczki, czereśnie, pomidory i kapusta pekińska były najczęściej badanymi produktami. Dane dotyczące liczby i rodzaju badanych próbek przedstawiono w tabeli 1., a listę oznaczanych związków w tabeli 2.

Tabela 1. Badane produkty

Table 1. Analysed products

\begin{tabular}{|c|c|c|c|}
\hline \multirow{2}{*}{ Produkt $^{1}$ - Product $^{1}$} & \multirow{2}{*}{$\begin{array}{c}\text { Liczba próbek } \\
\text { Number of samples }\end{array}$} & \multicolumn{2}{|c|}{ \% próbek - Percentage of samples } \\
\hline & & $\mathrm{A}^{2}$ & $\mathrm{~B}^{3}$ \\
\hline 1 & 2 & 3 & 4 \\
\hline Owoce - Fruits & 533 & 40,9 & - \\
\hline \multicolumn{4}{|c|}{ Owoce ziarnkowe - Pome fruits } \\
\hline Gruszki - Pears & 28 & 2,1 & 5,3 \\
\hline Jabłka - Apples & 120 & 9,2 & 22,5 \\
\hline \multicolumn{4}{|c|}{ Owoce pestkowe - Stone fruits } \\
\hline Brzoskwinie - Peaches & 33 & 2,5 & 6,2 \\
\hline Czereśnie - Sweet cherries & 50 & 3,8 & 9,4 \\
\hline Śliwki-Plums & 28 & 2,1 & 5,3 \\
\hline Wiśnie - Sour cherries & 20 & 1,5 & 3,8 \\
\hline \multicolumn{4}{|c|}{ Owoce jagodowe - Berries } \\
\hline Agrest - Gooseberries & 14 & 1,1 & 2,6 \\
\hline Maliny - Raspberries & 97 & 7,4 & 18,2 \\
\hline Porzeczki - Currants & 91 & 7,0 & 17,1 \\
\hline Truskawki - Strawberries & 33 & 2,5 & 6,2 \\
\hline Winogrona - Grapes & 19 & 1,5 & 3,6 \\
\hline Warzywa - Vegetables & 626 & 48,0 & - \\
\hline \multicolumn{4}{|c|}{ Warzywa korzeniowe i bulwiaste - Root and tuber vegetables } \\
\hline Buraki ćwikłowe - Beetroots & 16 & 1,2 & 2,6 \\
\hline Marchew - Carrots & 42 & 3,2 & 6,7 \\
\hline Pietruszka (korzeń) - Parsley (root) & 33 & 2,5 & 5,3 \\
\hline Rzodkiewka - Radish & 20 & 1,5 & 3,2 \\
\hline Seler korzeniowy - Celeriac & 34 & 2,6 & 5,4 \\
\hline Ziemniaki - Potatoes & 1 & 0,1 & 0,2 \\
\hline \multicolumn{4}{|c|}{ Warzywa cebulowe - Bulb vegetables } \\
\hline Cebula - Onion & 24 & 1,8 & 3,8 \\
\hline \multicolumn{4}{|c|}{ Warzywa owocowe - Fruiting vegetables } \\
\hline Ogórki - Cucumbers & 30 & 2,3 & 4,8 \\
\hline Papryka - Sweet pepper & 40 & 3,1 & 6,4 \\
\hline Pomidory - Tomatoes & 69 & 5,3 & 11,0 \\
\hline \multicolumn{4}{|c|}{ Warzywa kapustne - Brassica vegetables } \\
\hline Brokuły - Broccolis & 24 & 1,8 & 3,8 \\
\hline Kalafior - Cauliflower & 30 & 2,3 & 4,8 \\
\hline Kapusta głowiasta - Head cabbage & 31 & 2,4 & 5,0 \\
\hline Kapusta pekińska - Chinese cabbage & 62 & 4,8 & 9,9 \\
\hline \multicolumn{4}{|c|}{ Warzywa liściowe i świeże zioła - Leaf vegetables and fresh herbs } \\
\hline Sałata-Lettuce & 30 & 2,3 & 4,8 \\
\hline Koper-Dill & 32 & 2,5 & 5,1 \\
\hline \multicolumn{4}{|c|}{ Warzywa strączkowe - Legume vegetables } \\
\hline Bób - Broad bean & 27 & 2,1 & 4,3 \\
\hline Fasola szparagowa - String bean & 23 & 1,8 & 3,7 \\
\hline Groszek zielony - Green pea & 20 & 1,5 & 3,2 \\
\hline
\end{tabular}




\begin{tabular}{|c|c|c|c|}
\hline 1 & 2 & 3 & 4 \\
\hline \multicolumn{4}{|c|}{ Warzywa łodygowe - Stem vegetables } \\
\hline Por - Leek & 26 & 2,0 & 4,2 \\
\hline Szparagi - Asparagus & 8 & 0,6 & 1,3 \\
\hline \multicolumn{4}{|c|}{ Grzyby - Fungi } \\
\hline Pieczarki - Mushrooms & 4 & 0,3 & 0,6 \\
\hline Jadalne nasiona roślin strączkowych - Pulses & 2 & 0,2 & - \\
\hline Groch - Pea & 2 & 0,2 & 100,0 \\
\hline Nasiona oleiste - Oilseeds & 66 & 5,1 & - \\
\hline Nasiona rzepaku - Rapeseed & 66 & 5,1 & 100,0 \\
\hline Zboża-Cereals & 55 & 4,2 & - \\
\hline Jęczmień - Barley & 21 & 1,6 & 38,2 \\
\hline Kukurydza - Corn & 34 & 2,6 & 61,8 \\
\hline Rośliny cukrodajne - Sugar plants & 22 & 1,7 & - \\
\hline Burak cukrowy - Sugar beet root & 22 & 1,7 & 100,0 \\
\hline
\end{tabular}

${ }^{1}$ klasyfikacja produktów według Rozporządzenia (WE) 396/2005 - classification of products according to Regulation (EC) 396/2005

${ }^{2}$ procent całkowitej liczby badanych próbek - percentage of the total number of samples tested

${ }^{3}$ procent badanych próbek w danej grupie produktów - percentage of samples tested in individual product group

Tabela 2. Poszukiwane związki

Table 2. Analysed compounds

acephate, acetamiprid*, acrinathrin, aldicarb, aldicarb sulfone, aldicarb sulfoxide, aldrin, alpha-cypermethrin*, azinophos-ethyl, azinophos-methyl, beta-cyfluthrin*, bifenthrin*, bromopropylate, bromophos-ethyl, bromophosmethyl, buprofezin, cadusafos, carbaryl, carbofuran, carbosulfan, chlorantraniliprole, chlorfenvinfos, chlorpyrifos*, chlorpyrifos-methyl, clothianidin, cyfluthrin, cypermethrin*, DDT (sum of p,p' - DDD, p,p' - DDE, o,p'- DDT, p,p' - DDT), deltamethrin*, demeton-S-methyl, demeton-S-methyl sulfone, desmethyl pirimicarb, diazinon, dichlorvos, dicofol, dicrotophos, dieldrin, diflubenzuron, dimethoate*, alpha-endosulfan, beta-endosulfan, endosulfan sulphate, endrin, EPN, esfenvalerate*, ethion, etofenprox*, ethoprohos, etoxazole, fenazaquin*, fenchlorphos,

Insektycydy i akarycydy Insecticides and acaricides fenoxycarb, fenthion, fenitrothion, fenpyroximate*, fenpropathrin, fenvalerate*, fipronil, flonicamid*, formothion, fosthiazate, $\alpha-\mathrm{HCH}, \beta-\mathrm{HCH}, \gamma-\mathrm{HCH}$ (lindane), heptachlor, heptachlor endo-epoxide, heptachlor exo-epoxide, heptenophos, hexythiazox, 3-hydroxy-carbofuran, imidacloprid*, indoxacarb, isocarbophos, isofenphos, isofenphos methyl, isoprocarb, lambda-cyhalothrin*, malathion, mecarbam, malaoxon, methacriphos, methamidophos, methidathion, methiocarb, methiocarb sulfone, methiocarb sulfoxide, methomyl, methoxychlor, methoxyfenozide, mevinphos, monocrotophos, oxamyl, omethoate*, oxydemeton, paraoxon-ethyl, paraoxon-methyl, parathion-ethyl, parathion methyl, permethrin, phenthoate, phosalone*, phosmet, pyridaben*, pirimiphos-ethyl, pirimiphos-methyl*, pirimicarb*, piriproxyfen, propargite, pyrethrins, prophenophos, propoxur, quinalphos, spinosad, spirodiclofen*, tau-fluvalinate, tefluthrin, tebufenozide, tebufenpyrad*, tetrachlorvinphos, tetradifon, tetramethrin, thiacloprid*, thiamethoxam, triazophos, zeta-cypermethrin

azaconazole, azoxystrobin*, benalaxyl*, bitertanol, bromuconazole, boscalid*, bupirimate*, captan*, captafol, carbendazim*, carboxin*, chlorothalonil*, chlozolinate, cyazofamid, cyflufenamid, cymoxanil, cyprodinil*, cyproconazole, dichlofluanid, dicloran, difenoconazole*, diethofencarb, dimethomorph, dimoxystrobin, diniconazole, diphenylamine, dithiocarbamates ${ }^{1, *}$ (mancozeb, maneb, methiram, propineb, thiram, ziram) ${ }^{1}$, epoxiconazole*, etaconazole, famoxadone*, fenamidone, fenarimol, fenbuconazole, fenhexamid*, fenpropimorph*, fluchinconazole, Fungicydy fludioxonil*, fluopicolide*, fluoxastrobin, flusilazole*, flutolanil, flutriafol, folpet*, fuberidazole, HCB, hexaconazole, Fungicides imazalil, imibenconazole, ipconazole, iprodione*, iprovalicarb, isoprothiolane, krezoxim-methyl, mandipropamid, mepanipyrim*, metalaxyl (sum of metalaxyl and, metalaxyl-M)*, metconazole*, metrafenone*, myclobutanil, oxadiksyl, paclobutrazol, penconazole, pencycuron, phenmedipham, picoxystrobin*, prochloraz, procymidone, propiconazole*, proquinazid, prothioconazole-desthio, pyraclostrobin*, pyrazophos, pyrimethanil*, quinoxyfen, quintozene, spiroxamine, tebuconazole*, tecnazene, tetraconazole*, thiabendazole, tolclofos-methyl, tolylfluanid*, triadimefon, triadimenol, triazoxide, trifloxystrobin*, triflumizole, triticonazole, vinclozolin, zoxamide

Herbicydy i regulatory acetochlor, atrazine, bromacil, carfentrazone-ethyl, chloridazon, chlorotoluron, chloroxuron, chlorpropham, wzrostu Herbicides and growth regulatores chlorsulfuron, clomazone, cyanazine, cyprazine, desmedipham, diflufenican, dimethachlor, dimethenamid, diuron, ethofumesate, fenoxaprop P, flufenacet, fluorochloridone*, flurtamone, isoproturon, lenacil, linuron*, mesosulfuronmethyl, metamitron, metazachlor, metholachlor, metobromuron, mesotrione, metosulam, metribuzin, monolinuron, napropamide, nitrofen, oxyfluorfen, pendimethalin*, pethoxamid, prociazyne, propaquizafop, propazine, propham, promethrin, propachlor, propoxycarbazone-sodium, propyzamide, simazine, sulcotrione, sulfometuron-methyl, terbuthylazine, terbutryn, triasulfuron, trifluralin*, triflusulfuron-methyl, trinexapac-ethyl 
Do badań wykorzystano metody ilościowe, głównie wielopozostałościowe, bazujące na ekstrakcji pozostałości za pomocą rozpuszczalników organicznych oraz oczyszczaniu ekstraktu takimi technikami, jak: podział ciecz/ ciecz, ekstrakcja do fazy stałej (SPE - solid-phase extraction), dyspersyjna ekstrakcja do fazy stałej (dSPE dispersive solid-phase extraction). Badania instrumentalne opierały się na różnych technikach chromatograficznych: chromatografii gazowej i cieczowej z tandemową spektrometrią mas (GC-MS/MS, LC-MS/MS), chromatografii gazowej z detektorami selektywnymi - wychwytu elektronów i termojonowym (GC-ECD/NPD) oraz chromatografii cieczowej z detektorem fotodiodowym (HPLC-PDA). Do oznaczeń wykonywanych za pomocą chromatografów cieczowych i gazowych sprzężonych ze spektrometrią mas próbki zostały przygotowane techniką QuEChERS (Walorczyk 2008; Walorczyk i Drożdżyński 2011). W analizie pozostałości ditiokarbaminianów, oznaczanych jako $\mathrm{CS}_{2}$, zastosowano metodę spektrofotometryczną (Chmiel 1979). Wyniki badań potwierdzono zgodnie z wytycznymi zawartymi w unijnym dokumencie dotyczącym walidacji metod i procedur jakości w analizie żywności i pasz (Method 2011). Laboratoria biorace udział w badaniach potwierdzały stale swoje kompetencje analityczne w zakresie prowadzonych badań poprzez uczestnictwo w międzynarodowych badaniach biegłości, organizowanych przez Laboratoria Referencyjne Unii Europejskiej ${ }^{1}$ oraz FAPAS ${ }^{2}$. Wyniki badań były oceniane pod kątem zgodności $\mathrm{z}$ najwyższymi dopuszczalnymi poziomami pozostałości (NPD) wziąwszy pod uwagę 50\% wartość niepewności rozszerzonej, obligatoryjną w urzędowych badaniach pozostałości pestycydów w żywności i paszach w krajach Unii Europejskiej (Method 2011).

\section{Wyniki i dyskusja / Results and discussion}

Pozostałości ś.o.r. nie wykryto w 882 próbkach kontrolowanych płodów rolnych $(67,6 \%)$, natomiast ich obecność stwierdzono w 422 próbkach $(32,4 \%)$. Próbki $\mathrm{z}$ jedną pozostałością stanowiły $16,7 \%$ badanych próbek, podczas gdy próbki $\mathrm{z}$ wieloma pozostałościami 15,6\%, w tym głównie dwóch $(8,2 \%)$ i trzech $(3,6 \%)$ związków. Odsetki próbek owoców, warzyw, nasion oleistych, roślin cukrodajnych i suchych nasion strączkowych zawierających pozostałości ś.o.r. kształtowały się odpowiednio na poziomie: 46,$5 ; 24,1 ; 27,3 ; 18,2$ i 50,0\%. Udziały procentowe próbek z pozostałościami nieprzekraczającymi i przekraczającymi NDP zarówno dla ogółu próbek, jak również dla poszczególnych grup produktów przedstawia rysunek 1., a próbek z wieloma pozostałościami rysunek 2 .

Pozostałości ś.o.r. stwierdzono w 31 spośród 38 badanych produktów (rys. 3). Częstość ich występowania była zróżnicowana i mieściła się $\mathrm{w}$ zakresie $3,8-78,6 \%$, w tym

${ }^{1}$ EURL-Proficiency Test-FV-15, 2013. Pesticide Residues in Potato Homogenate. Final report.

EUPT-CF7, 2013. Report on Proficiency Test on incurred and spiked pesticides in feed. Final report.

EUPT-SRM8, 2013. EU Proficiency Test on the Analysis of Spiked Pesticides in Potato Homogenates. Final report.

${ }^{2}$ FAPAS - The Food Analysis Performance Assessment Scheme, FERA, York, UK. Proficiency Test 19147. Pesticide Residues in Pear Purée. w granicach 3,8-18,2\% dla 9 produktów (por, fasola szparagowa, rzodkiewka, groszek zielony, burak ćwikłowy, kapusta głowiasta, papryka, burak cukrowy, brzoskwinia) oraz $21,9-46,4 \%$ dla 15 produktów (koper, sałata, szparag, brokuł, śliwka, ogórek, nasiona rzepaku, winogrono, wiśnia, korzeń pietruszki, malina, seler korzeniowy, kapusta pekińska, czereśnia, pomidor), zaś była najwyższa w agreście (78,6\%), truskawkach $(69,7 \%)$, marchwi $(59,5 \%)$, jabłkach $(56,7 \%)$, gruszkach $(53,6 \%)$ i porzeczkach $(51,6 \%)$.

Łącznie wykryto pozostałości 60 poszukiwanych związków, w tym 33 z grupy insektycydów i akarycydów, 24 fungicydów i 4 herbicydów (tab. 2). Głównie stwierdzano pozostałości środków grzybobójczych (66,4\%), rzadziej pozostałości środków owadobójczych i roztoczobójczych (30,3\%), zaś sporadycznie chwastobójczych $(3,3 \%)$. Poszczególne substancje czynne wykrywano w 0,1-14,1\% próbek (rys. 4). Najczęściej stwierdzano pozostałości: ditiokarbaminianów $(14,1 \%)$, karbendazymu $(6,5 \%)$, boskalidu $(4,9 \%)$, tiachloprydu $(4,7 \%)$, kaptanu $(4,4 \%)$, linuronu $(4,4 \%)$, chloropiryfosu $(4,1 \%)$, azoksystrobiny $(3,5 \%)$, piraklostrobiny $(2,9 \%)$, cyprodynilu $(2,5 \%)$, difenokonazolu $(2,2 \%)$ i pirymetanilu $(2,1 \%)$.

Zaobserwowano różnice $\mathrm{w}$ liczbie i rodzaju wykrywanych pozostałości $\mathrm{w}$ poszczególnych produktach, co wynika z różnorakiego asortymentu substancji czynnych dopuszczonych do ochrony upraw, jak i sposobu ich stosowania. Największą różnorodność występujących pozostałości stwierdzono w jabłkach (25 związków), w kapuście pekińskiej (18 związków) oraz w czereśniach i porzeczkach (16 związków). Czternaście związków wykrywano $\mathrm{w}$ niektórych produktach $\mathrm{z}$ częstością równą lub wyższą 20\%: azoksystrobinę - w sałacie, boskalid - w truskawkach i marchwi, bupirymat - w agreście, cyprodynil - w truskawkach, chloropiryfos - w marchwi i kapuście pekińskiej, difenokonazol - w agreście, ditiokarbaminiany - w jabłkach, agreście, porzeczkach i truskawkach, fludioksonil - w truskawkach, kaptan - w gruszkach i jabłkach, karbendazym - w brzoskwiniach, czereśniach, śliwkach, porzeczkach i pomidorach, linuron - w selerze, pirymetanil - w malinach, tebukonazol w śliwkach, tiachlopryd - w czereśniach i porzeczkach. Szczegółowe dane odnośnie odsetków i zakresów stężeń wykrytych związków w badanych produktach podano w tabeli 3.

Przeprowadzone badania wykazały dwojakiego rodzaju nieprawidłowości w stosowaniu środków - przekroczenia najwyższych dopuszczalnych poziomów pozostałości (NDP) i stosowanie preparatów niedopuszczonych do ochrony upraw. Z tego tytułu wystawiono 99 powiadomień alarmowych RASFF dla płodów rolnych zawierających pozostałości ś.o.r. przekraczające dozwolone limity i/lub pozostałości niedozwolonych związków. Zawierały one m.in. szczegółowe informacje o pochodzeniu takich produktów i rodzaju odnotowanych naruszeń. Na ich podstawie PIORiN podejmował stosowne działania wobec producentów nieprzestrzegających prawa.

Wykryte stężenie pozostałości uznawano za niezgodne z wymaganiami (Rozporządzenie 2005), gdy poziom pozostałości przekraczał najwyższy dopuszczalny poziom, wziąwszy pod uwagę 50\% niepewność pomiaru, tak jak to 


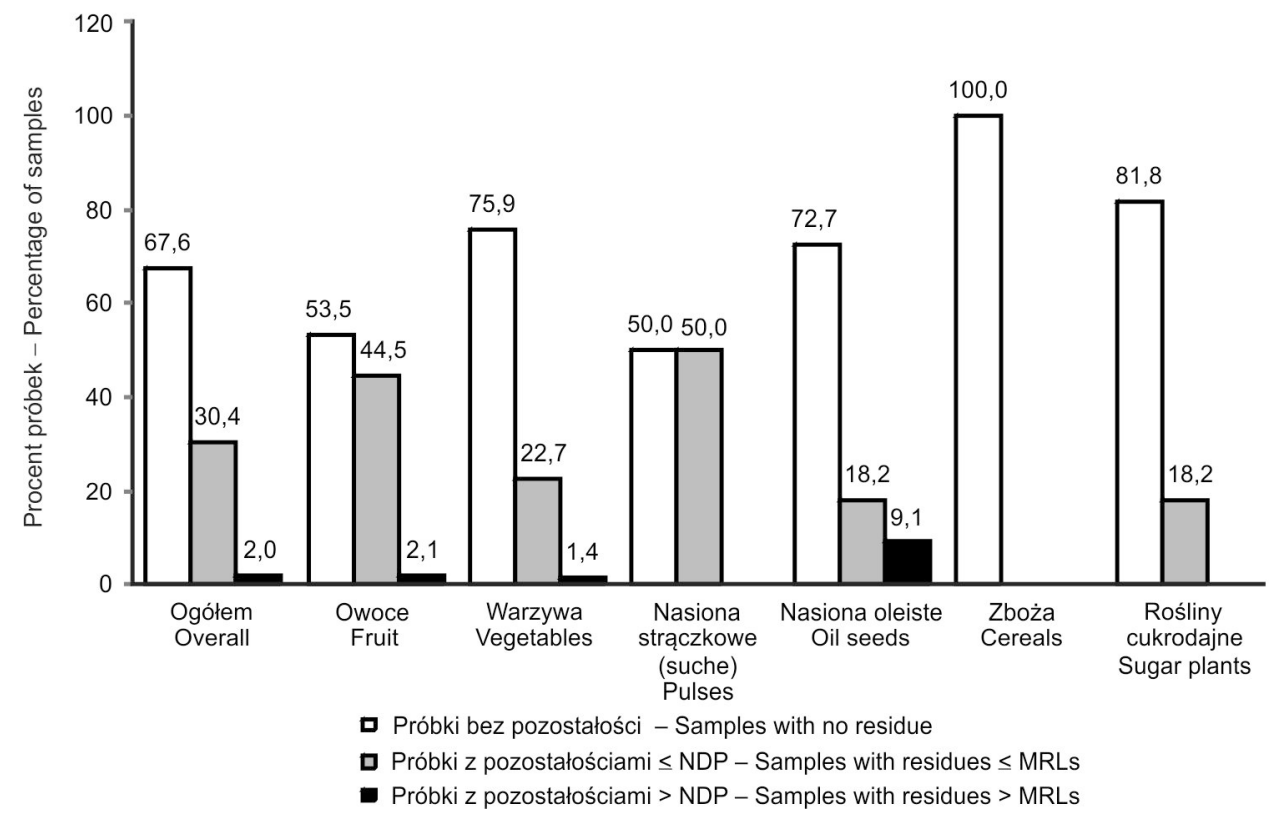

Rys. 1. Odsetek próbek z lub bez pozostałości oraz z pozostałościami przekraczającymi NDP w roku 2013 (ogólny, grupy produktów) Fig. 1. Percentage of samples with and without measurable residues, and residues exceeding the MRLs in 2013 (total, product groups)

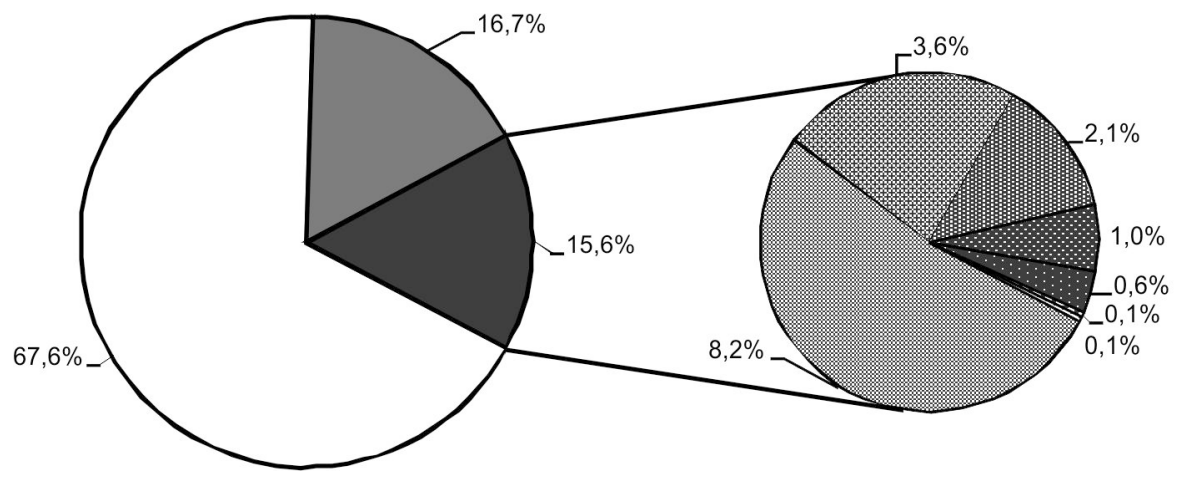

- Bez pozostałości - Without residues

- 1 pozostałość -1 residue

政 2 pozostałości -2 residues

- 3 pozostałości -3 residues

*3 4 pozostałości -4 residues

- 5 pozostałości -5 residues

D 6 pozostałości -6 residues

Rys. 2. Odsetek próbek z wieloma pozostałościami (2013)

Fig. 2. The percentage of samples with multiple residues (2013)

przewiduje prawodawstwo unijne (Method 2011). Takich niezgodności było niewiele $(2,0 \%)$ i dotyczyły one 11 produktów oraz 15 substancji czynnych (tab. 4). W 24 próbkach stwierdzono przekroczenie NDP dla jednego związku, a w 2 próbkach (agrest, czarna porzeczka) dla dwóch związków. Zbyt wysokie stężenia pozostałości ś.o.r. wykrywano przede wszystkim w agreście (14,3\%), porzeczkach $(8,8 \%)$ i ziarnie rzepaku $(9,1 \%)$. Dla kombinacji ziarno rzepaku/pirymifos metylowy odnotowano najwyższy procent przekroczeń NDP $(7,6 \%)$. Blisko połowa naruszeń $(0,9 \%)$ była spowodowana zastosowaniem środków niezatwierdzonych do ochrony uprawy. Pozostałe mogły wynikać z nieprzestrzegania zalecanej dawki środka albo metody aplikacji bądź okresu karencji, ale także z wykonania nadmiernej liczby zabiegów.

Nieco większy wymiar, aniżeli przekroczenia NDP, miało stosowanie niezarejestrowanych substancji. Stwierdzono ponad 3-krotnie wyższy odsetek przypadków takiego łamania prawa (tab. 5). W 85 próbkach $(6,5 \%)$, zaobserwowano obecność pozostałości środków niedopuszczonych do ich ochrony, przy czym w 21 próbkach więcej niż jednego związku, maksymalnie zaś czterech. Nieprawidłowości te dotyczyły 32 substancji czynnych, w tym głównie fungicydów, łącznie w 24 rodzajach upraw warzywnych i sadowniczych (tab. 3). Odnotowano niedozwolone stosowanie 21 substancji grzybobójczych: azoksystrobiny (brokuł, ogórek, pietruszka, winorośl), boskalidu (czereśnia, kapusta pekińska, papryka, pietruszka), chlorotalonilu (czereśnia, pietruszka, sałata), difenokonazolu (czereśnia, pietruszka), ditiokarbaminianów (brzoskwinia, czereśnia, szparag), epoksykonazolu (burak ćwikłowy, rzepak, seler), etofenproksu (brokuł, kapusta pekińska), fenpropimorfu (agrest), fluopikolidu (winorośl, pomidor), flusilazolu (agrest, czereśnia, porzeczka), folpetu (malina), kaptanu (brzoskwinia, czereśnia, malina), karbendazymu (brokuł, brzoskwinia, czereśnia, kapusta pekińska, porzeczka), metrafenonu (agrest), metkonazolu (kapusta pekińska), pikoksystrobiny (pietruszka, seler), 
pirymetanilu (kapusta pekińska), piraklostrobiny (czereśnia, kapusta pekińska, pietruszka), propikonazolu (agrest, pietruszka, seler), tebukonazolu (czereśnia, kapusta pekińska, pietruszka, seler), tolylfluanidu (porzeczka), trifloksystrobiny (agrest, winorośl). Wykryto także przypadki użycia 7 niedopuszczonych substancji owadobójczych: bifentryny (jabłoń, kapusta pekińska), chloropiryfosu (grusza, jabłoń, koper, pietruszka, seler), cypermetryny (seler), dimetoatu (czereśnia, groszek zielony, kapusta pekińska, wiśnia), fenazachiny (jabłoń), fosalonu (rzodkiewka), imidachloprydu (kapusta pekińska) oraz 3 substancji chwastobójczych - linuronu (koper), pendimetaliny (koper), trifluraliny (marchew).

Problem używania środków niedozwolonych najwyraźniej uwidocznił się $\mathrm{w}$ uprawach czereśni, szparaga, pietruszki, winorośli, kopru, selera korzeniowego, brokułu, agrestu i kapusty pekińskiej, gdzie odsetek naruszeń był stosunkowo duży i wynosił odpowiednio - 32,0; 25,0; 24,$2 ; 21,1 ; 18,8 ; 17,6 ; 16,7 ; 14,3 ; 14,3 ;$ i $12,9 \%$. $\mathrm{W}$ próbkach pochodzących $\mathrm{z}$ upraw czereśni, kapusty pekińskiej i korzenia pietruszki znaleziono wiele niedopuszczonych substancji, odpowiednio - jedenaście, dziesięć i dziewięć, co bardzo wyraźnie wskazuje na niedostateczne spektrum środków do ich ochrony, zwłaszcza z grupy grzybobójczych. Do ochrony upraw czereśni producenci mieli do wyboru zaledwie kilka substancji czynnych, co niestety, skłaniało do częstszego sięgania po środki zalecane wyłącznie do ochrony wiśni, zawierające, np. kaptan, difenokonazol, tebukonazol czy tiuram. Analogiczna sytuacja miała miejsce w uprawie pietruszki i selera, gdzie obserwowane naruszenia polegały, na ogół, na stosowaniu preparatów przeznaczonych tylko do zwalczania agrofagów w marchwi, zawierających m.in. azoksystrobinę, tebukonazol lub chlorotalonil.

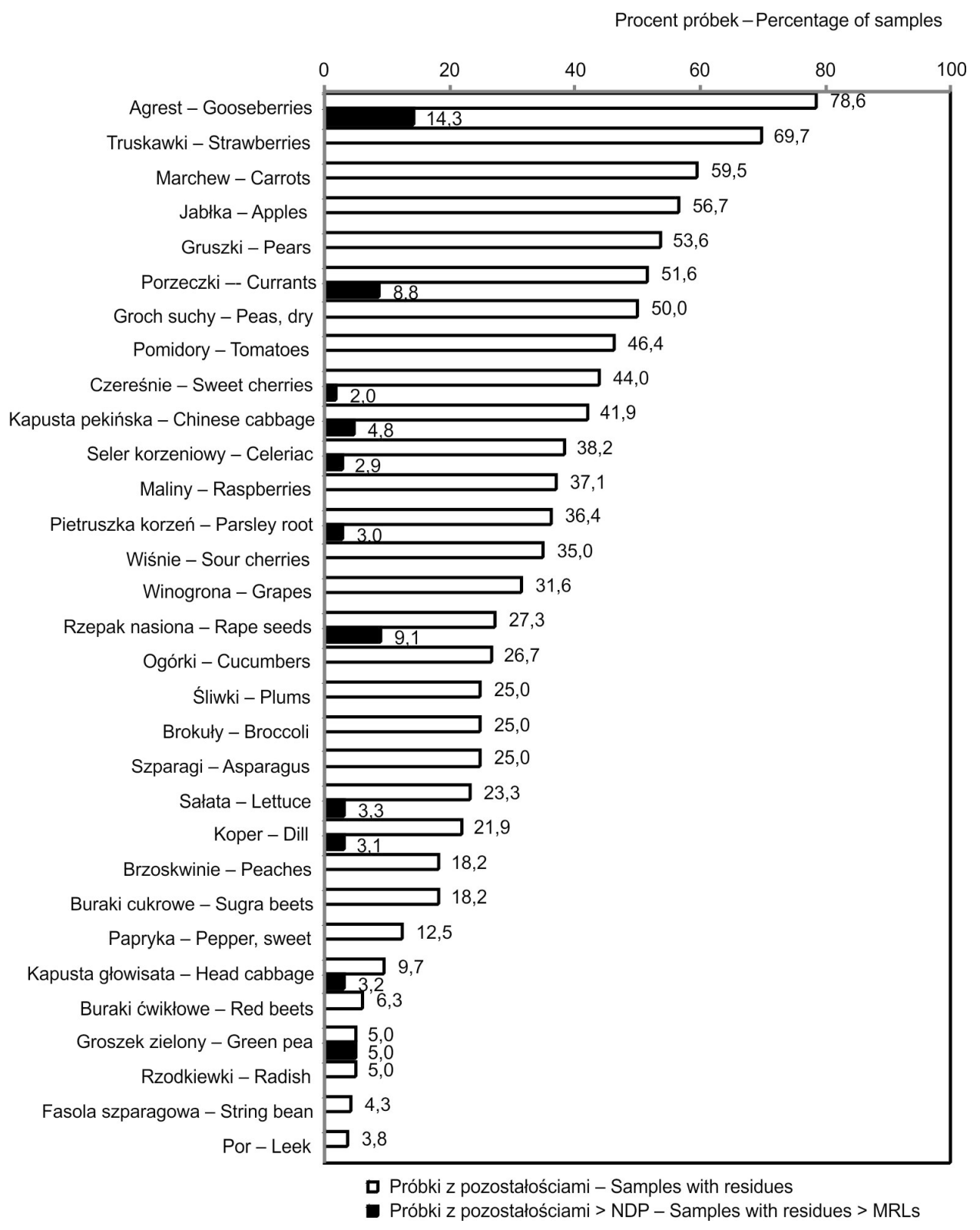

Rys. 3. Częstotliwość występowania pozostałości środków ochrony roślin w poszczególnych produktach (2013)

Fig. 3. The frequency of pesticide residue occurrence in individual products (2013) 


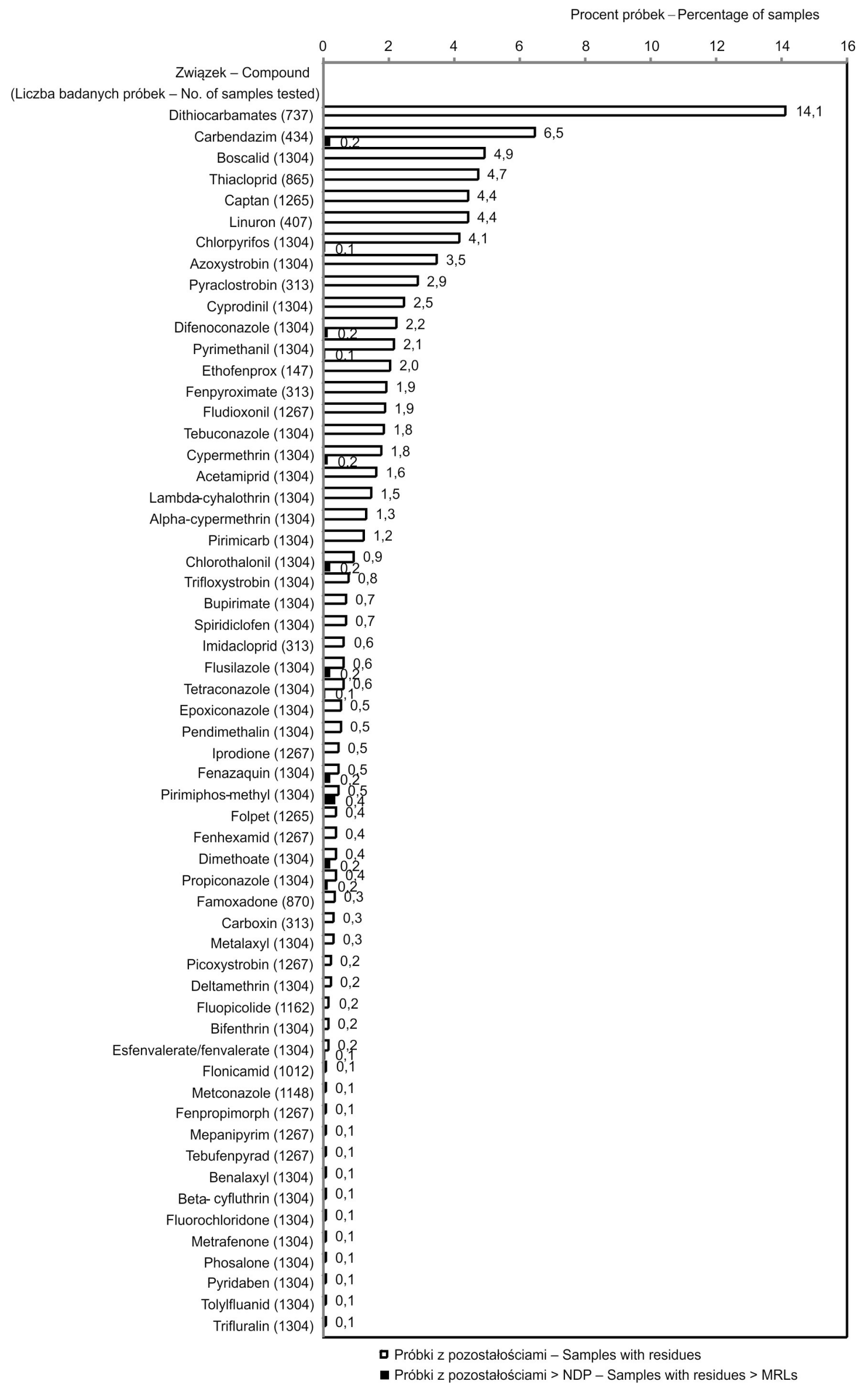

Rys. 4. Częstotliwość wykrywania poszczególnych związków (2013)

Fig. 4. The frequency of occurrence of the compounds detected (2013) 
Tabela 3. Pozostałości środków ochrony roślin wykryte w poszczególnych produktach

Table 3. Pesticide residues detected in individual products

\begin{tabular}{|c|c|c|c|c|c|}
\hline \multirow{2}{*}{$\begin{array}{l}\text { Produkt } \\
\text { Product }\end{array}$} & \multirow{2}{*}{$\begin{array}{l}\text { Związek } \\
\text { Compound }\end{array}$} & \multirow{2}{*}{$\begin{array}{c}\text { Liczba } \\
\text { badanych } \\
\text { próbek } \\
\text { Number } \\
\text { of analysed } \\
\text { samples }\end{array}$} & \multicolumn{2}{|c|}{$\begin{array}{c}\text { Próbki } \\
\text { z pozostałościami } \\
\text { Samples with residues }\end{array}$} & \multirow{2}{*}{$\begin{array}{c}\text { Zakres wykrywanych } \\
\text { pozostałości } \\
\text { Range of found residues } \\
{[\mathrm{mg} / \mathrm{kg}]}\end{array}$} \\
\hline & & & $\begin{array}{c}\text { liczba } \\
\text { number }\end{array}$ & $\begin{array}{c}\text { procent } \\
\text { percentage }\end{array}$ & \\
\hline 1 & 2 & 3 & 4 & 5 & 6 \\
\hline \multicolumn{6}{|c|}{ Owoce - Fruits } \\
\hline \multicolumn{6}{|c|}{ Owoce ziarnkowe - Pome fruits } \\
\hline \multirow{11}{*}{ Gruszki - Pears } & acetamiprid & 28 & 2 & 7,1 & $0,01-0,02$ \\
\hline & boscalid & 28 & 2 & 7,1 & $0,01-0,02$ \\
\hline & captan & 28 & 11 & 39,3 & $0,02-0,50$ \\
\hline & chlorpyrifos $^{1}$ & 28 & 1 & 3,6 & 0,06 \\
\hline & cypermethrin & 28 & 1 & 3,6 & 0,01 \\
\hline & cyprodinil & 28 & 1 & 3,6 & 0,75 \\
\hline & dithiocarbamates & 28 & 5 & 17,9 & $0,05-0,23$ \\
\hline & fludioxonil & 28 & 1 & 3,6 & 0,21 \\
\hline & flusilazole & 28 & 1 & 3,6 & 0,02 \\
\hline & pirimicarb & 28 & 2 & 7,1 & $0,02-0,03$ \\
\hline & thiacloprid & 19 & 2 & 10,5 & $0,02-0,04$ \\
\hline \multirow{25}{*}{ Jabłka - Apples } & acetamiprid & 120 & 7 & 5,8 & $0,01-0,04$ \\
\hline & bifenthrin $^{1}$ & 120 & 1 & 0,8 & 0,02 \\
\hline & boscalid & 120 & 6 & 5,0 & $0,02-0,29$ \\
\hline & captan & 120 & 33 & 27,5 & $0,01-1,69$ \\
\hline & carbendazim & 120 & 2 & 1,7 & $0,03-0,08$ \\
\hline & chlorpyrifos $^{1}$ & 120 & 7 & 5,8 & $0,02-0,27$ \\
\hline & cypermethrin & 120 & 4 & 3,3 & $0,04-0,06$ \\
\hline & cyprodinil & 120 & 4 & 3,3 & $0,03-0,16$ \\
\hline & dithiocarbamates & 120 & 25 & 20,8 & $0,05-1,06$ \\
\hline & fenazaquin $^{1}$ & 120 & 3 & 2,5 & $0,04-0,11$ \\
\hline & fenpyroximate & 117 & 2 & 1,7 & $0,01-0,01$ \\
\hline & flonicamid & 88 & 1 & 1,1 & 0,02 \\
\hline & fludioxonil & 120 & 2 & 1,7 & $0,03-0,09$ \\
\hline & flusilazole & 120 & 3 & 2,5 & $0,01-0,02$ \\
\hline & imidacloprid & 117 & 1 & 0,9 & 0,04 \\
\hline & lambda-cyhalothrin & 120 & 1 & 0,8 & 0,03 \\
\hline & pirimicarb & 120 & 7 & 5,8 & $0,01-0,08$ \\
\hline & pirydaben & 120 & 1 & 0,8 & 0,02 \\
\hline & propiconazole & 120 & 1 & 0,8 & 0,01 \\
\hline & pyraclostrobin & 117 & 1 & 0,9 & 0,17 \\
\hline & pyrimethanil & 120 & 4 & 3,3 & $0,06-0,16$ \\
\hline & spirodiclofen & 120 & 9 & 7,5 & $0,01-0,06$ \\
\hline & tebuconazole & 120 & 4 & 3,3 & $0,01-0,09$ \\
\hline & thiacloprid & 77 & 3 & 3,9 & $0,02-0,04$ \\
\hline & trifloxystrobin & 120 & 4 & 3,3 & $0,01-0,11$ \\
\hline \multicolumn{6}{|c|}{ Owoce pestkowe - Stone fruits } \\
\hline \multirow{5}{*}{ Brzoskwinie - Peaches } & $\operatorname{captan}^{1}$ & 33 & 1 & 3,0 & 0,13 \\
\hline & carbendazim $^{1}$ & 11 & 3 & 27,3 & $0,02-0,04$ \\
\hline & difenoconazole & 33 & 1 & 3,0 & 0,04 \\
\hline & dithiocarbamates $^{1}$ & 33 & 3 & 9,1 & $0,07-2,00$ \\
\hline & pirimicarb & 33 & 2 & 6,1 & $0,01-0,04$ \\
\hline
\end{tabular}




\begin{tabular}{|c|c|c|c|c|c|}
\hline 1 & 2 & 3 & 4 & 5 & 6 \\
\hline \multirow{16}{*}{ Czereśnie - Sweet cherries } & acetamiprid & 50 & 8 & 16,0 & $0,01-0,10$ \\
\hline & alpha-cypermethrin & 50 & 4 & 8,0 & $0,01-0,09$ \\
\hline & boscalid $^{1}$ & 50 & 3 & 6,0 & $0,01-0,47$ \\
\hline & $\operatorname{captan}^{1}$ & 50 & 6 & 12,0 & $0,02-0,35$ \\
\hline & carbendazim $^{1}$ & 32 & 9 & 28,1 & $0,01-0,11$ \\
\hline & chlorothalonil $^{1}$ & 50 & 1 & 2,0 & 0,08 \\
\hline & cypermethrin & 50 & 3 & 6,0 & $0,07-0,10$ \\
\hline & difenoconazole ${ }^{1}$ & 50 & 1 & 2,0 & 0,04 \\
\hline & dimethoate $^{1}$ & 50 & 2 & 4,0 & $0,08-0,34$ \\
\hline & dithiocarbamates $^{1}$ & 50 & 1 & 2,0 & 0,10 \\
\hline & flusilazole $^{1}$ & 50 & 1 & 2,0 & 0,02 \\
\hline & $\begin{array}{l}\text { omethoate (dimethoate } \\
\text { metabolite) })^{1}\end{array}$ & 32 & 1 & 3,1 & 0,10 \\
\hline & pirimicarb & 50 & 4 & 8,0 & $0,01-0,04$ \\
\hline & pyraclostrobin $^{1}$ & 32 & 2 & 6,3 & $0,02-0,08$ \\
\hline & tebuconazole $^{1}$ & 50 & 2 & 4,0 & $0,01-0,32$ \\
\hline & thiacloprid & 35 & 8 & 22,9 & $0,01-0,12$ \\
\hline \multirow{5}{*}{ Śliwki - Plums } & carbendazim & 9 & 3 & 33,3 & $0,05-2,00$ \\
\hline & dithiocarbamates & 28 & 1 & 3,6 & 0,29 \\
\hline & fenpyroximate & 9 & 1 & 11,1 & 0,06 \\
\hline & tebuconazole & 28 & 6 & 21,4 & $0,01-0,21$ \\
\hline & thiacloprid & 22 & 1 & 4,5 & 0,01 \\
\hline \multirow{9}{*}{ Wiśnie - Sour cherries } & acetamiprid & 20 & 1 & 5,0 & 0,01 \\
\hline & alpha-cypermethrin & 20 & 2 & 10,0 & $0,01-0,01$ \\
\hline & boscalid & 20 & 1 & 5,0 & 0,01 \\
\hline & captan & 20 & 3 & 15,0 & $0,04-0,74$ \\
\hline & difenoconazole & 20 & 1 & 5,0 & 0,07 \\
\hline & dithiocarbamates & 20 & 2 & 10,0 & $0,06-0,10$ \\
\hline & $\begin{array}{l}\text { omethoate (dimethoate } \\
\text { metabolite) }{ }^{1}\end{array}$ & 3 & 1 & 33,3 & 0,02 \\
\hline & pirimicarb & 20 & 1 & 5,0 & 0,06 \\
\hline & tebuconazole & 20 & 1 & 5,0 & 0,57 \\
\hline \multicolumn{6}{|c|}{ Owoce jagodowe - Berries } \\
\hline \multirow{11}{*}{ Agrest - Gooseberries } & alpha-cypermethrin & 14 & 2 & 14,3 & $0,01-0,032$ \\
\hline & bupirimate & 14 & 8 & 57,1 & $0,01-0,82$ \\
\hline & carbendazim & 3 & 1 & 33,3 & 0,01 \\
\hline & difenoconazole & 14 & 7 & 50 & $0,02-0,27$ \\
\hline & dithiocarbamates & 14 & 4 & 28,6 & $0,17-2,43$ \\
\hline & epoxiconazole & 14 & 1 & 7,1 & 0,188 \\
\hline & fenpropimorph $^{1}$ & 14 & 1 & 7,1 & 0,576 \\
\hline & flusilazole $^{1}$ & 14 & 1 & 7,1 & 0,286 \\
\hline & metrafenone $^{1}$ & 14 & 1 & 7,1 & 0,04 \\
\hline & propiconazole $^{1}$ & 14 & 1 & 7,1 & 0,78 \\
\hline & trifloxystrobin $^{1}$ & 14 & 1 & 7,1 & 0,02 \\
\hline \multirow{8}{*}{ Maliny - Raspberries } & boscalid & 97 & 12 & 12,4 & $0,02-2,16$ \\
\hline & captan $^{1}$ & 97 & 2 & 2,1 & $0,04-0,42$ \\
\hline & chlorpyrifos & 97 & 1 & 1,0 & 0,01 \\
\hline & cyprodinil & 97 & 12 & 12,4 & $0,02-0,42$ \\
\hline & fenhexamid & 97 & 4 & 4,1 & $0,16-1,10$ \\
\hline & fludioxonil & 97 & 8 & 8,2 & $0,03-0,34$ \\
\hline & folpet $^{1}$ & 97 & 4 & 4,1 & $0,02-1,28$ \\
\hline & iprodione & 97 & 1 & 1,0 & 0,38 \\
\hline
\end{tabular}




\begin{tabular}{|c|c|c|c|c|c|}
\hline 1 & 2 & 3 & 4 & 5 & 6 \\
\hline & lambda-cyhalothrin & 97 & 1 & 1,0 & 0,01 \\
\hline & pyrimethanil & 97 & 21 & 21,6 & $0,01-3,00$ \\
\hline & thiacloprid & 11 & 2 & 18,2 & $0,05-0,05$ \\
\hline \multirow{16}{*}{ Porzeczki - Currants } & alpha-cypermethrin & 91 & 8 & 8,8 & $0,03-0,40$ \\
\hline & boscalid & 91 & 5 & 5,5 & $0,02-3,31$ \\
\hline & carbendazim $^{1}$ & 19 & 5 & 26,3 & $0,03-0,25$ \\
\hline & chlorpyrifos & 91 & 2 & 2,2 & $0,02-0,03$ \\
\hline & cypermethrin & 91 & 6 & 6,6 & $0,03-0,22$ \\
\hline & cyprodinil & 91 & 2 & 2,2 & $0,04-0,08$ \\
\hline & deltamethrin & 91 & 2 & 2,2 & $0,01-0,08$ \\
\hline & difenoconazole & 91 & 18 & 19,8 & $0,03-0,43$ \\
\hline & dithiocarbamates & 91 & 32 & 35,2 & $0,08-2,74$ \\
\hline & fenazaquin & 91 & 3 & 3,3 & $0,03-0,19$ \\
\hline & fenpyroximate & 19 & 2 & 10,5 & $0,03-0,20$ \\
\hline & fludioxonil & 91 & 1 & 1,1 & 0,05 \\
\hline & flusilazole $^{1}$ & 91 & 2 & 2,2 & $0,05-0,08$ \\
\hline & lambda-cyhalothrin & 91 & 16 & 17,6 & $0,01-0,12$ \\
\hline & thiacloprid & 68 & 21 & 30,9 & $0,01-0,81$ \\
\hline & tolylfluanid $^{1}$ & 91 & 1 & 1,1 & 0,03 \\
\hline \multirow{12}{*}{ Truskawki - Strawberries } & boscalid & 33 & 10 & 30,3 & $0,01-0,39$ \\
\hline & bupirimate & 33 & 1 & 3,0 & 0,01 \\
\hline & cyprodinil & 33 & 7 & 21,2 & $0,01-0,24$ \\
\hline & dithiocarbamates & 33 & 8 & 24,2 & $0,08-0,23$ \\
\hline & fenhexamid & 33 & 1 & 3,0 & 0,67 \\
\hline & fludioxonil & 33 & 7 & 21,2 & $0,01-0,13$ \\
\hline & folpet & 33 & 1 & 3,0 & 0,23 \\
\hline & iprodione & 33 & 1 & 3,0 & 0,09 \\
\hline & mepanipyrim & 33 & 1 & 3,0 & 0,01 \\
\hline & pyrimethanil & 33 & 2 & 6,0 & $0,08-0,09$ \\
\hline & pyraclostrobin & 3 & 1 & 33,3 & 0,02 \\
\hline & tetraconazole & 33 & 1 & 3,0 & 0,03 \\
\hline \multirow{7}{*}{ Winogrona - Grapes } & azoxystrobin $^{1}$ & 19 & 2 & 10,5 & $0,02-0,02$ \\
\hline & cyprodinil & 19 & 3 & 15,8 & $0,03-0,16$ \\
\hline & dithiocarbamates & 19 & 3 & 15,8 & $0,06-0,17$ \\
\hline & fludioxonil & 19 & 3 & 15,8 & $0,01-0,05$ \\
\hline & fluopicolide $^{1}$ & 18 & 1 & 5,6 & 0,01 \\
\hline & metalaxyl & 19 & 2 & 10,5 & $0,02-0,02$ \\
\hline & trifloxystrobin $^{1}$ & 19 & 2 & 10,5 & $0,25-0,28$ \\
\hline \multicolumn{6}{|c|}{ Warzywa - Vegetables } \\
\hline \multicolumn{6}{|c|}{ Warzywa korzeniowe - Root vegetables } \\
\hline Buraki ćwikłowe - Beet roots & epoxiconazole $^{1}$ & 16 & 1 & 6,3 & 0,01 \\
\hline \multirow{11}{*}{ Marchew - Carrots } & azoxystrobin & 42 & 5 & 11,9 & $0,03-0,04$ \\
\hline & boscalid & 42 & 9 & 21,4 & $0,02-0,35$ \\
\hline & chlorpyrifos & 42 & 16 & 38,1 & $0,01-0,18$ \\
\hline & cypermethrin & 42 & 1 & 2,4 & 0,01 \\
\hline & cyprodinil & 42 & 1 & 2,4 & 0,07 \\
\hline & fludioxonil & 42 & 1 & 2,4 & 0,07 \\
\hline & linuron & 42 & 3 & 7,1 & $0,01-0,03$ \\
\hline & pyraclostrobin & 17 & 2 & 11,8 & $0,01-0,01$ \\
\hline & tebuconazole & 42 & 4 & 9,5 & $0,01-0,05$ \\
\hline & trifloxystrobin & 42 & 1 & 2,4 & 0,01 \\
\hline & trifluralin $^{1}$ & 42 & 1 & 2,4 & 0,02 \\
\hline
\end{tabular}




\begin{tabular}{|c|c|c|c|c|c|}
\hline 1 & 2 & 3 & 4 & 5 & 6 \\
\hline \multirow{12}{*}{$\begin{array}{l}\text { Pietruszka (korzeń) } \\
\text { Parsley root }\end{array}$} & azoxystrobin $^{1}$ & 33 & 2 & 6,1 & $0,01-0,05$ \\
\hline & boscalid $^{1}$ & 33 & 3 & 9,1 & $0,03-0,08$ \\
\hline & chlorothalonil $^{1}$ & 33 & 1 & 3,0 & 0,05 \\
\hline & chlorpyrifos $^{1}$ & 33 & 4 & 12,1 & $0,01-0,02$ \\
\hline & difenoconazole ${ }^{1}$ & 33 & 1 & 3,0 & 0,11 \\
\hline & fluorochloridone & 33 & 1 & 3,0 & 0,03 \\
\hline & linuron & 33 & 4 & 12,1 & $0,02-0,10$ \\
\hline & pendimethalin & 33 & 3 & 9,1 & $0,01-0,02$ \\
\hline & picoxystrobin $^{1}$ & 33 & 1 & 3,0 & 0,01 \\
\hline & propiconazole $^{1}$ & 33 & 1 & 3,0 & 0,01 \\
\hline & pyraclostrobin $^{1}$ & 11 & 2 & 18,2 & $0,02-0,03$ \\
\hline & tebuconazole $^{1}$ & 33 & 2 & 6,1 & $0,02-0,03$ \\
\hline Rzodkiewka-Radish & phosalone $^{\text {l }}$ & 20 & 1 & 5,0 & 0,02 \\
\hline \multirow{9}{*}{ Seler korzeniowy - Celeriac } & azoxystrobin & 34 & 4 & 11,8 & $0,04-0,07$ \\
\hline & chlorpyrifos $^{1}$ & 34 & 2 & 5,9 & $0,04-0,09$ \\
\hline & cypermethrin $^{1}$ & 34 & 1 & 2,9 & 0,03 \\
\hline & dithiocarbamates & 34 & 2 & 5,9 & $0,07-0,13$ \\
\hline & epoxiconazole $^{1}$ & 34 & 2 & 5,9 & $0,01-0,03$ \\
\hline & linuron & 34 & 8 & 23,5 & $0,01-0,25$ \\
\hline & picoxystrobin $^{1}$ & 34 & 1 & 2,9 & 0,08 \\
\hline & propiconazole $^{1}$ & 34 & 2 & 5,9 & $0,02-0,13$ \\
\hline & tebuconazole $^{1}$ & 34 & 1 & 2,9 & 0,02 \\
\hline \multicolumn{6}{|c|}{ Warzywa owocowe - Fruiting vegetables } \\
\hline \multirow{4}{*}{ Ogórki-Cucumbers } & azoxystrobin $^{1}$ & 30 & 2 & 6,7 & $0,06-0,11$ \\
\hline & chlorothalonil & 30 & 1 & 3,3 & 0,35 \\
\hline & dithiocarbamates & 30 & 5 & 16,7 & $0,05-0,20$ \\
\hline & metalaxyl & 30 & 2 & 6,7 & $0,02-0,07$ \\
\hline \multirow{5}{*}{ Papryka - Sweet pepper } & azoxystrobin & 40 & 2 & 5,0 & $0,014-0,29$ \\
\hline & boscalid $^{1}$ & 40 & 1 & 2,5 & 0,01 \\
\hline & dithiocarbamates & 40 & 1 & 2,5 & 0,06 \\
\hline & pyrimethanil & 40 & 1 & 2,5 & 0,02 \\
\hline & tebufenpyrad & 40 & 1 & 2,5 & 0,04 \\
\hline \multirow{12}{*}{ Pomidory - Tomatoes } & azoxystrobin & 69 & 11 & 15,9 & $0,01-0,13$ \\
\hline & benalaxyl & 69 & 1 & 1,4 & 0,01 \\
\hline & boscalid & 69 & 9 & 13,0 & $0,02-0,26$ \\
\hline & carbendazim & 4 & 1 & 25,0 & 0,19 \\
\hline & chlorothalonil & 69 & 7 & 10,1 & $0,01-0,55$ \\
\hline & cyprodinil & 69 & 1 & 1,4 & 0,03 \\
\hline & deltamethrin & 69 & 1 & 1,4 & 0,05 \\
\hline & dithiocarbamates & 69 & 10 & 14,5 & $0,05-0,42$ \\
\hline & famoxadone & 48 & 3 & 6,3 & $0,03-0,17$ \\
\hline & fludioxonil & 69 & 1 & 1,4 & 0,01 \\
\hline & fluopicolide $^{1}$ & 63 & 1 & 1,6 & 0,02 \\
\hline & iprodione & 69 & 3 & 4,3 & $0,06-0,60$ \\
\hline \multicolumn{6}{|c|}{ Warzywa kapustne - Brassica vegetables } \\
\hline \multirow{6}{*}{ Brokuły - Broccoli } & azoxystrobin $^{1}$ & 24 & 1 & 4,2 & 0,068 \\
\hline & carbendazim $^{1}$ & 10 & 1 & 10,0 & 0,09 \\
\hline & chlorpyrifos & 24 & 2 & 8,3 & $0,05-0,06$ \\
\hline & esfenvalerate & 24 & 1 & 4,2 & 0,007 \\
\hline & etofenprox ${ }^{1}$ & 10 & 2 & 20,0 & $0,01-0,07$ \\
\hline & fenvalerate & 24 & 1 & 4,2 & 0,007 \\
\hline
\end{tabular}




\begin{tabular}{|c|c|c|c|c|c|}
\hline 1 & 2 & 3 & 4 & 5 & 6 \\
\hline \multirow{4}{*}{$\begin{array}{l}\text { Kapusta głowiasta } \\
\text { Head cabbage }\end{array}$} & azoxystrobin & 31 & 2 & 6,5 & $0,018-0,08$ \\
\hline & dimethoate & 31 & 1 & 3,2 & 0,07 \\
\hline & lambda-cyhalothrin & 31 & 1 & 3,2 & 0,007 \\
\hline & $\begin{array}{l}\text { omethoate (dimethoate } \\
\text { metabolite) }\end{array}$ & 14 & 1 & 7,1 & 0,06 \\
\hline \multirow{18}{*}{$\begin{array}{l}\text { Kapusta pekińska } \\
\text { Chinese cabbage }\end{array}$} & azoxystrobin & 62 & 7 & 11,3 & $0,02-0,267$ \\
\hline & bifenthrin $^{1}$ & 62 & 1 & 1,6 & 0,08 \\
\hline & boscalid $^{1}$ & 62 & 1 & 1,6 & 0,582 \\
\hline & chlorpyrifos & 62 & 17 & 27,4 & $0,03-0,75$ \\
\hline & cypermethrin & 62 & 5 & 8,1 & $0,018-0,56$ \\
\hline & dimethoate $^{1}$ & 62 & 1 & 1,6 & 0,08 \\
\hline & esfenvalerate & 62 & 1 & 1,6 & 0,027 \\
\hline & etofenprox ${ }^{1}$ & 23 & 1 & 4,3 & 0,03 \\
\hline & fenvalerate & 62 & 1 & 1,6 & 0,054 \\
\hline & imidacloprid $^{1}$ & 23 & 1 & 4,3 & 0,01 \\
\hline & iprodione & 39 & 1 & 2,6 & 0,04 \\
\hline & carbendazim $^{1}$ & 23 & 3 & 13,0 & $0,01-0,16$ \\
\hline & metconazole $^{1}$ & 59 & 1 & 1,7 & 0,14 \\
\hline & pyrimethanil $^{1}$ & 62 & 1 & 1,6 & 0,11 \\
\hline & pyraclostrobin $^{1}$ & 23 & 1 & 4,3 & 0,04 \\
\hline & tebuconazole ${ }^{1}$ & 62 & 1 & 1,6 & 0,07 \\
\hline & thiacloprid & 51 & 1 & 2,0 & 0,02 \\
\hline & trifloxystrobin & 62 & 2 & 3,2 & $0,02-0,29$ \\
\hline \multicolumn{6}{|c|}{ Warzywa liściowe i świeże zioła - Leaf vegetables and fresh herbs } \\
\hline \multirow{4}{*}{ Sałata - Lettuce } & azoxystrobin & 30 & 6 & 20,0 & $0,01-2,95$ \\
\hline & chlorothalonil $^{1}$ & 30 & 1 & 3,3 & 0,16 \\
\hline & cypermethrin & 30 & 1 & 3,3 & 0,04 \\
\hline & cyprodinil & 30 & 1 & 3,3 & 0,024 \\
\hline \multirow{5}{*}{ Koper - Dill } & alpha-cypermethrin & 32 & 1 & 3,1 & 0,163 \\
\hline & chlorpyrifos $^{1}$ & 32 & 1 & 3,1 & 0,13 \\
\hline & cypermethrin & 32 & 1 & 3,1 & 0,193 \\
\hline & linuron $^{1}$ & 32 & 3 & 9,4 & $0,03-0,06$ \\
\hline & pendimethalin $^{1}$ & 32 & 4 & 12,5 & $0,04-0,186$ \\
\hline \multicolumn{6}{|c|}{ Warzywa strączkowe - Legume vegetables } \\
\hline Fasola szparagowa - String bean & chlorothalonil & 23 & 1 & 4,3 & 0,03 \\
\hline Groszek zielony - Green pea & dimethoate $^{1}$ & 20 & 1 & 5,0 & 0,08 \\
\hline \multicolumn{6}{|c|}{ Warzywa łodygowe - Stem vegetables } \\
\hline Por - Leek & azoxystrobin & 26 & 1 & 3,8 & 0,013 \\
\hline Szparagi - Asparagus & dithiocarbamates $^{1}$ & 8 & 2 & 25 & $0,06-0,12$ \\
\hline \multicolumn{6}{|c|}{ Jadalne nasiona roślin strączkowych - Pulses } \\
\hline Groch - Pea & carboxin & 2 & 1 & 50,0 & 0,01 \\
\hline \multicolumn{6}{|c|}{ Nasiona oleiste - Oilseeds } \\
\hline \multirow{8}{*}{ Nasiona rzepaku - Rapeseed } & acetamiprid & 33 & 3 & 9,1 & $0,01-0,03$ \\
\hline & boscalid & 66 & 2 & 3,0 & $0,02-0,04$ \\
\hline & epoxiconazole ${ }^{1}$ & 66 & 1 & 1,5 & 0,06 \\
\hline & picoxystrobin & 33 & 1 & 3,0 & 0,02 \\
\hline & pirimiphos-methyl & 66 & 5 & 7,6 & $0,12-0,42$ \\
\hline & tebuconazole & 66 & 3 & 4,5 & $0,03-0,06$ \\
\hline & tetraconazole & 66 & 7 & 10,6 & $0,02-0,41$ \\
\hline & thiacloprid & 59 & 3 & 5,1 & $0,02-0,05$ \\
\hline
\end{tabular}




\begin{tabular}{|c|c|c|c|c|c|}
\hline 1 & 2 & 3 & 4 & 5 & 6 \\
\hline \multicolumn{6}{|c|}{ Rośliny cukrodajne - Sugar plants } \\
\hline \multirow{3}{*}{ Burak cukrowy - Sugar beet root } & beta-cyfluthrin & 22 & 1 & 4,5 & 0,06 \\
\hline & chlorpyrifos & 22 & 1 & 4,5 & 0,02 \\
\hline & epoxiconazole & 22 & 2 & 9,1 & $0,01-0,02$ \\
\hline
\end{tabular}

${ }^{1}$ Pozostałości substancji czynnych niepoduszczonych do stosowania - Residues of unauthorised plant protection products

Tabela 4. Produkty, w których stwierdzono przekroczenia najwyższych dopuszczalnych poziomów pozostałości

Table 4. Products with residues exceeding maximum residue levels

\begin{tabular}{|c|c|c|c|c|c|c|}
\hline \multirow[b]{2}{*}{$\begin{array}{l}\text { Produkt } \\
\text { Product }\end{array}$} & \multirow[b]{2}{*}{$\begin{array}{l}\text { Związek } \\
\text { Compound }\end{array}$} & \multirow{2}{*}{$\begin{array}{c}\text { Liczba } \\
\text { badanych } \\
\text { Próbek } \\
\text { Number } \\
\text { of } \\
\text { analysed } \\
\text { samples }\end{array}$} & \multicolumn{2}{|c|}{$\begin{array}{l}\text { Przekroczenia NDP }{ }^{1} \\
\text { MRLs exceedances }\end{array}$} & \multirow{2}{*}{$\begin{array}{l}\text { Poziom pozostałości } \\
\text { Residue level } \\
{[\mathrm{mg} / \mathrm{kg}]}\end{array}$} & \multirow{2}{*}{$\begin{array}{r}\mathrm{NDP}^{1} \\
\mathrm{MRLs} \\
{[\mathrm{mg} / \mathrm{kg}]}\end{array}$} \\
\hline & & & $\begin{array}{l}\text { liczba } \\
\text { number }\end{array}$ & $\begin{array}{l}\text { procent } \\
\text { percent }\end{array}$ & & \\
\hline \multirow{3}{*}{ Agrest - Gooseberries } & difenoconazole & 14 & 1 & 7,1 & 0,27 & 0,1 \\
\hline & flusilazole $^{2}$ & \multirow{2}{*}{14} & \multirow{2}{*}{1} & \multirow{2}{*}{7,1} & 0,268 & 0,02 \\
\hline & propiconazole $^{2}$ & & & & 0,078 & 0,05 \\
\hline Czereśnie - Sweet cherries & chlorothalonil $^{2}$ & 50 & 1 & 2,0 & 0,08 & 0,01 \\
\hline Groszek zielony - Green pea & dimethoate $^{2}$ & 20 & 1 & 5,0 & 0,08 & 0,02 \\
\hline $\begin{array}{l}\text { Kapusta głowiasta } \\
\text { Head cabbage }\end{array}$ & dimethoate & 31 & 1 & 3,2 & 0,12 & 0,02 \\
\hline \multirow{3}{*}{$\begin{array}{l}\text { Kapusta pekińska } \\
\text { Chinese cabbage }\end{array}$} & dimethoate $^{2}$ & 62 & 1 & 1,6 & 0,08 & 0,02 \\
\hline & $\begin{array}{l}\text { sum of fenvalerate } \\
\text { and esfenvalerate }\end{array}$ & 62 & 1 & 1,6 & 0,081 & 0,02 \\
\hline & pyrimethanil $^{2}$ & 62 & 1 & 1,6 & 0,11 & 0,05 \\
\hline Koper - Dill & chlorpyrifos $^{2}$ & 32 & 1 & 3,1 & 0,13 & 0,05 \\
\hline $\begin{array}{l}\text { Pietruszka korzeń } \\
\text { Parsley root }\end{array}$ & chlorothalonil $^{2}$ & 33 & 1 & 3,0 & 0,05 & 0,01 \\
\hline \multirow{7}{*}{ Porzeczki - Currants } & carbendazim $^{2}$ & 19 & 1 & 5,3 & 0,25 & 0,1 \\
\hline & cypermethrin & 91 & 1 & 1,1 & 0,14 & 0,05 \\
\hline & cypermethrin & \multirow{2}{*}{91} & \multirow{2}{*}{1} & \multirow{2}{*}{1,1} & 0,22 & 0,05 \\
\hline & flusilazole $^{2}$ & & & & 0,08 & 0,02 \\
\hline & difenoconazole & 91 & 1 & 1,1 & 0,43 & 0,05 \\
\hline & fenazaquin & 91 & 3 & 3,3 & 0,19 & 0,01 \\
\hline & flusilazole $^{2}$ & 91 & 1 & 1,1 & 0,05 & 0,02 \\
\hline \multirow{2}{*}{ Rzepak nasiona - Rapeseed } & pirimiphos-methyl & 66 & 5 & 7,6 & $0,12-0,42$ & 0,05 \\
\hline & tetraconazole & 66 & 1 & 1,5 & 0,41 & 0,15 \\
\hline Sałata-Lettuce & chlorothalonil $^{2}$ & 30 & 1 & 3,3 & 0,16 & 0,01 \\
\hline Seler korzeniowy - Celeriac & propiconazole $^{2}$ & 34 & 1 & 2,9 & 0,13 & 0,05 \\
\hline Ogółem - Overall & & 1304 & 26 & 2,0 & - & - \\
\hline
\end{tabular}

${ }^{1}$ Najwyższe dopuszczalne poziomy pozostałości - Maximum Residue Levels

${ }^{2}$ Niedopuszczona substancja aktywna - unauthorised active substance

Problem niedostatku środków do ochrony wielu roślin małoobszarowych, głównie upraw warzywnych, sadowniczych i zielarskich, pojawił się wraz z wycofaniem wielu preparatów $\mathrm{z}$ rynku, wynikającym $\mathrm{z}$ przeprowadzenia przeglądu substancji czynnych przez UE, którego celem było pozostawienie $\mathrm{w}$ obrocie jedynie tych bezpiecznych dla zdrowia ludzi i środowiska. Jedynym sposobem na ograniczanie procederu stosowania środków niedozwo- lonych jest ciagłe rozszerzanie zakresu zezwoleń na uprawy małoobszarowe. Proces ten, niestety, jest bardzo powolny, ale każdego roku pojawiają się zmiany w rejestrze środków dopuszczonych do ochrony warzyw, owoców i ziół, np. choćby jedne $\mathrm{z}$ ostatnich bardzo istotnych, polegające na poszerzeniu zakresu stosowania dwóch preparatów fungicydowych - Signum 33 WG (boskalid i piraklostrobina) oraz Switch 62,5 WG (cyprodynil, 
Tabela 5. Produkty z pozostałościami środków niedopuszczonych

Table 5. Products with residues of unauthorised plant protection products

\begin{tabular}{|c|c|c|c|c|}
\hline \multirow[t]{2}{*}{$\begin{array}{l}\text { Produkt } \\
\text { Product }\end{array}$} & \multirow{2}{*}{$\begin{array}{l}\text { Liczba } \\
\text { badanych } \\
\text { próbek } \\
\text { Number of } \\
\text { analysed } \\
\text { samples }\end{array}$} & \multicolumn{2}{|c|}{$\begin{array}{c}\text { Próbki z pozostałościami związków } \\
\text { niedopuszczonych } \\
\text { Samples with residues } \\
\text { of unapproved compounds }\end{array}$} & \multirow{2}{*}{$\begin{array}{c}\text { Liczba } \\
\text { niedopuszczonych } \\
\text { związków } \\
\text { Number of unapproved } \\
\text { compounds }\end{array}$} \\
\hline & & $\begin{array}{l}\text { liczba } \\
\text { number }\end{array}$ & $\begin{array}{l}\text { procent } \\
\text { percent }\end{array}$ & \\
\hline Czereśnie - Sweet cherries & 50 & 16 & 32,0 & 11 \\
\hline Szparagi - Asparagus & 8 & 2 & 25,0 & 1 \\
\hline Pietruszka korzeń - Parsley root & 33 & 8 & 24,2 & 9 \\
\hline Winogrona - Grapes & 19 & 4 & 21,1 & 3 \\
\hline Koper - Dill & 32 & 6 & 18,8 & 3 \\
\hline Seler korzeniowy - Celeriac & 34 & 6 & 17,6 & 6 \\
\hline Brokuły - Broccoli & 24 & 4 & 16,7 & 3 \\
\hline Agrest - Gooseberries & 14 & 2 & 14,3 & 5 \\
\hline Kapusta pekińska - Chinese cabbage & 62 & 8 & 12,9 & 10 \\
\hline Ogórki - Cucumbers & 30 & 2 & 6,7 & 1 \\
\hline Burak ćwikłowy - Beet root & 16 & 1 & 6,3 & 1 \\
\hline Maliny - Raspberries & 97 & 6 & 6,2 & 2 \\
\hline Jabłka - Apples & 120 & 6 & 5,0 & 3 \\
\hline Groszek zielony - Green pea & 20 & 1 & 5,0 & 1 \\
\hline Rzodkiewka-Radish & 20 & 1 & 5,0 & 1 \\
\hline Wiśnie - Sour cherries & 20 & 1 & 5,0 & 1 \\
\hline Gruszki - Pears & 28 & 1 & 3,6 & 1 \\
\hline Sałata-Lettuce & 30 & 1 & 3,3 & 1 \\
\hline Brzoskwinie - Peaches & 33 & 1 & 3,0 & 3 \\
\hline Papryka - Sweet peppers & 40 & 1 & 2,5 & 1 \\
\hline Marchew - Carrots & 42 & 1 & 2,4 & 1 \\
\hline Porzeczki - Currants & 91 & 4 & 4,4 & 3 \\
\hline Rzepak - Rape seed & 66 & 1 & 1,5 & 1 \\
\hline Pomidory - Tomatoes & 69 & 1 & 1,4 & 1 \\
\hline Ogółem - Overall & 1304 & 85 & 6,5 & 32 \\
\hline
\end{tabular}

fludioksonil) (Etykieta 2013, 2015). Należy podkreślić, że z tym problemem boryka się nie tylko Polska, ale cała UE, dlatego niedawno podjęto wspólnotowe działania na rzecz ograniczenia luk w obszarze małoobszarowych zastosowań ś.o.r. (Decyzja 2014; Report 2014).

Wyniki z 2013 roku wskazują, że większość rodzimych płodów rolnych pochodzących $\mathrm{z}$ produkcji pierwotnej $(98,0 \%)$ spełniała wymagania dotyczące najwyższych dopuszczalnych poziomów pozostałości pestycydów, ponieważ nie zawierały one wcale pozostałości lub ich stężenia mieściły się $\mathrm{w}$ dozwolonym zakresie. Procent przekroczeń NDP $(2,0 \%)$ i przypadków stosowania środków niedopuszczonych (6,5\%) świadczą o ich zwyżce w odniesieniu do lat ubiegłych. W roku 2011 oraz 2012 pierwszy rodzaj naruszeń stanowił odpowiednio 0,6 i 0,4\%, zaś drugi - 2,5 oraz 2,2\% (Nowacka i wsp. 2012, 2014). Zważywszy, iż błędy w stosowaniu środków obserwuje się głównie dla upraw warzywnych i sadowniczych (Pesticide 2011, 2012; Nowacka i wsp. 2012, 2014; Scientific Report $2014 \mathrm{a}, \mathrm{b})$ oraz wziąwszy pod uwagę proporcje badanych grup produktów w 2013 roku można uznać, że tak duży procentowy przyrost nieprawidłowości mógł się przede wszystkim wiązać z blisko 90\% udziałem warzyw i owoców w badaniach. Jednakże w przypadku naruszeń NDP na całą pulę przekroczeń złożyło się także kilka odnotowanych przekroczeń w ziarnie rzepaku, które bardzo wyraźnie zaważyły na całej statystyce.

Wyniki badań wskazują także na wzrost częstości występowania pozostałości ś.o.r., gdyż średni odsetek wykryć w 2011 i 2012 roku wynosił odpowiednio 21,7 i 17,0\% (Nowacka i wsp. 2012, 2014), co znowu można wiązać $\mathrm{z}$ częstszym, niż w latach poprzednich, badaniem warzyw i owoców aniżeli zbóż skażonych zwykle w dużo mniejszym stopniu. Przeciętne zanieczyszczenie owoców pozostałościami ś.o.r. było na poziomie 46,5\%, czyli niższym niż w roku $2011(58,7 \%)$, ale z kolei wyższym niż w 2012 roku (30,1\%) (Nowacka i wsp. 2012, 2014). Warzywa rzadziej zawierały pozostałości ś.o.r. (24,5\%), przy czym różnica procentowa $\mathrm{w}$ częstotliwości ich wykrywania $\mathrm{w}$ porównaniu $\mathrm{z}$ rokiem 
2011, kiedy to wynosiła 23,8\% (Nowacka i wsp. 2012), stanowi niecały procent, natomiast w stosunku do roku 2012, gdy była równa 17,5\% (Nowacka i wsp. 2014) jest kilkuprocentowa.

Odnosząc wyniki badań do danych za poprzednie lata i zważywszy, że w każdym roku badania urzędowe cechowała zmienność rodzaju i liczby badanych obiektów oraz stały wzrost liczby oznaczanych związków, można powiedzieć, że w roku 2013 zwiększyła się nieco skala przekroczeń NDP, jak i przypadków stosowania środków niedozwolonych, ale ogólne tendencje w występowaniu pozostałości ś.o.r. były zbliżone.

Skala stwierdzonych ponadnormatywnych pozostałości pestycydów jest porównywalna $\mathrm{z}$ notowaną dla produktów żywnościowych na rynku UE, czy też wyprodukowanych w Stanach Zjednoczonych, na co wskazują ostatnie dostępne dane statystyczne $\mathrm{z}$ monitoringów żywności przeprowadzonych w latach 2011-2012. Według raportów opracowanych przez Europejski Urząd ds. Bezpieczeństwa Żywności, w roku 2011 i 2012 odsetek żywności niespełniającej wymagań wynosił dla skoordynowanego monitoringu UE odpowiednio 1,1 i $0,5 \%$, natomiast w przypadku monitoringów krajowych państw członkowskich - 1,5 i 1,2\% (Scientific Report 2014a, b). Z raportów Amerykańskiej Agencji Żywności i Leków wynika, że w tych latach przekroczenia tolerancji dotyczyły 1,6 i 2,8\% produktów (Pesticide 2011, 2012). Porównując wyniki badań do tych statystyk można również uznać, że polska roślinna produkcja pierwotna była $\mathrm{w}$ nieco mniejszym stopniu zanieczyszczona pozostałościami ś.o.r. niż żywność w obrocie w UE, a także amerykańska, gdyż w 2011 i 2012 roku zostały one wykryte odpowiednio w 46,6 i 40,1\% produktów pochodzących z rynku unijnego (Scientific Report 2014a, b) oraz w 39,5 i 43,0\% żywności z USA (Pesticide 2011, 2012). Ponadto widać, że pozostałości ś.o.r. występują w krajowych płodach rolnych na etapie produkcji pierwotnej podobnie często, jak w rodzimej żywności na rynku, bo zgodnie $\mathrm{z}$ danymi ze skoordynowanego monitoringu UE z roku 2011 i 2012 były one obecne odpowiednio w 27,5 i 21,6\% polskich produktów w obrocie (Scientific 2014a, b).

Podsumowując wyniki badań należy zaznaczyć, że urzędowa kontrola pozostałości ś.o.r. w produkcji pierwotnej nie ma charakteru ściśle losowego, ponieważ głównie koncentruje się na obszarach potencjalnych zagrożeń (przekroczenia NDP, stosowanie substancji niedopuszczonych). Ma ona na celu diagnozowanie ewentualnych nieprawidłowości w stosowaniu środków, a wszystkie problemy zidentyfikowane w tym zakresie służą w praktyce do podejmowania działań zmierzających do ich ograniczenia, poprzez dyscyplinowanie producentów (edukacja, nakładanie kar) oraz wprowadzanie zmian w przepisach dotyczących stosowania środków. Należy jednakże mieć świadomość, że wszelkie decyzje o wycofaniu już zarejestrowanych substancji lub ograniczeniu ich stosowania zawsze przekładają się na zwiększenie liczby naruszeń prawa w zakresie stosowania środków, ponieważ proces dostosowywania się producentów rolnych do nowych regulacji jest przeważnie procesem wykraczającym poza ramy czasowe określone przepisami.

\section{Wnioski / Conclusions}

1. Zdecydowana większość badanych rodzimych płodów rolnych (98\%) spełniała wymagania prawa żywnościowego w zakresie najwyższych dopuszczalnych poziomów pozostałości pestycydów, przy czym aż 67,6\% produktów nie zawierało pozostałości ś.o.r.

2. Pozostałości ś.o.r. występowały najliczniej w owocach, zaś najczęściej w agreście, truskawkach, jabłkach, gruszkach i porzeczkach.

3. W warzywach pozostałości ś.o.r. wykrywano wyraźnie rzadziej aniżeli w owocach, głównie w marchwi, pomidorach, kapuście pekińskiej, selerze korzeniowym i korzeniu pietruszki.

4. Skala łamania prawa w zakresie stosowania ś.o.r. była niewielka. Przypadki stosowania niedozwolonych ś.o.r. oraz przekroczenia NDP występowały z różnym nasileniem. Zjawisko marginalne stanowiły przekroczenia NDP $(2,0 \%)$, natomiast stosowanie niedopuszczonych substancji czynnych zdarzało się kilkakroć częściej (6,5\%), co można wiązać z niedoborem ś.o.r. do ochrony upraw małoobszarowych.

5. Wyniki badań potwierdzają skuteczność urzędowej kontroli prowadzonej $\mathrm{W}$ zakresie pozostałości ś.o.r. w roślinnej produkcji pierwotnej, jak również konieczność stałego nadzoru nad stosowaniem ś.o.r.

\section{Literatura / References}

Chmiel Z. 1979. Spektrofotometryczne oznaczanie śladowych pozostałości dwutiokarbaminianów w materiale roślinnym. Chemia Analityczna 24: 505-511.

Decyzja wykonawcza Komisji z dnia 17 listopada 2014 r. dotycząca zmiany programu prac na rok 2014 objętego decyzją wykonawczą Komisji 2014/C 166/05 oraz przyjęcia programu prac i finansowania działań w zakresie żywności i paszy na rok 2015 w celu zapewnienia stosowania prawodawstwa dotyczącego żywności i paszy. 2014. Dz. U. C 410 z 18.11 .2014 r., s. 3-9.

Dyrektywa Parlamentu Europejskiego i Rady 2009/128/WE z dnia 21 października 2009 r. ustanawiająca ramy wspólnotowego działania na rzecz zrównoważonego stosowania pestycydów 2009. Dz. U. L 309/71 z 24.11.2009 r., s. 71 .

Etykieta Signum 33 WG, załącznik nr 1 do decyzji MRiRW nr R-281/2013d z dnia 14.11.2013 r. zmieniającej zezwolenie MRiRW nr R-33/2010 z dnia 19.04.2010 r. 2013.

Etykieta Switch 62,5 WG, załącznik nr 1 do decyzji MRiRW nr R-71/2015d z dnia 06.02.2015 r. zmieniającej zezwolenie MRiRW nr R-73/2011 z dnia 05.12.2011 r. 2015.

Method validation and quality control procedures for pesticide residues analysis in food and feed. 2011. Document No. SANCO/ 12495/2011. Supersedes Document No. SANCO/10684/2009. Implemented by 01.01.2012. 
Nowacka A., Gnusowski B., Walorczyk S., Drożdżyński D., Raczkowski M., Hołodyńska-Kulas A., Frąckowiak D., Wójcik A., Ziółkowski A., Przewoźniak M., Swoboda W., Rzeszutko U., Domańska I., Jurys J., Łozowicka B., Kaczyński P., Rutkowska E., Jankowska M., Hrynko I., Szpyrka E., Rupar J., Rogozińska K., Kurdziel A., Słowik-Borowiec M., Szala J., Szponik M., Michel M. 2012. Pozostałości środków ochrony roślin w płodach rolnych (rok 2011). [Pesticide residues in Polish crops (2011)]. Progress in Plant Protection/Postępy w Ochronie Roślin 52 (4): 1106-1116.

Nowacka A., Gnusowski B., Walorczyk S., Drożdżyński D., Raczkowski M., Hołodyńska-Kulas A., Frąckowiak D., Wójcik A., Ziółkowski A., Przewoźniak M., Swoboda W., Rzeszutko U., Domańska I., Pszczolińska K., Łozowicka B., Kaczyński P., Rutkowska E., Jankowska M., Hrynko I., Szpyrka E., Rupar J., Rogozińska K., Kurdziel A., Słowik-Borowiec M., Szala J., Szponik M. 2014. Pozostałości środków ochrony roślin w płodach rolnych (rok 2012). [Pesticide residues in agricultural crops (2012)]. Progress in Plant Protection 54 (2): 219-230.

Pesticide Monitoring Program. 2011. Pesticide Report. U.S. Food and Drug Administration. www.fda.gov/downloads/Food/ FoodborneIllnessContaminants/Pesticides/UCM382443.pdf [Accessed: 16.02.2015].

Pesticide Monitoring Program. Fiscal Year 2012. Pesticide Report. U.S. Food and Drug Administration. http://www.fda.gov/ downloads/Food/FoodborneIllnessContaminants/Pesticides/UCM432758.pdf [Accessed: 17.02.2015].

Report from the Commission to the European Parliament and the Council on the establishment of a European fund for minor uses in the field of plant protection products Brussels. 2014. Com (2014) 82 final, 18.02.2014.

Rozporządzenie (WE) nr 178/2002 Parlamentu Europejskiego i Rady z dnia 28 stycznia 2002 r. ustanawiające ogólne zasady i wymagania prawa żywnościowego, powołującym Europejski Urząd ds. Bezpieczeństwa Żywności oraz ustanawiającym procedury w zakresie bezpieczeństwa żywności. 2002. Dz. U. L 31, s. 1 z dnia 01.02.2002 r. z późn. zm.; polskie wydanie specjalne: rozdz. 15, t. 6 , s. 463 .

Rozporządzenie (WE) nr 396/2005 Parlamentu Europejskiego i Rady z dnia 23 lutego 2005 r. w sprawie najwyższych dopuszczalnych poziomów pozostałości pestycydów w żywności i paszy pochodzenia roślinnego i zwierzęcego oraz na ich powierzchni, zmieniające dyrektywę Rady 91/414/EWG. 2005. Dz. U. L 70 z 16.03.2005, s. 1.

Rozporządzenie Ministra Zdrowia z dnia 17 października 2007 r. w sprawie pobierania próbek żywności w celu oznaczania poziomów pozostałości pestycydów. 2007. Dz. U. nr 207, poz. 1502.

Rozporządzenie Parlamentu Europejskiego i Rady (WE) nr 1107/2009 z dnia 21 października 2009 r. dotyczące wprowadzania do obrotu środków ochrony roślin i uchylające dyrektywy Rady 79/117/EWG i 91/414/EWG. 2009. Dz. U. L 309/1 z 24.11.2009 r., s. 1.

Rozporządzenie Komisji (UE) nr 16/2011 z dnia 10 stycznia 2011 r. ustanawiające środki wykonawcze dla systemu wczesnego ostrzegania o niebezpiecznych produktach żywnościowych i środkach żywienia zwierząt. 2011. Dz. U. L 6, z 10.01.2011 r., s. 7.

Scientific Report of EFSA. 2014a. The 2011 European Union Report on Pesticide Residues in Food. EFSA Journal 12 (5), p. 3694.

Scientific Report of EFSA. 2014b. The 2012 European Union Report on Pesticide Residues in Food. EFSA Journal 12 (12), p. 3942.

Uchwała nr 161/2011 Rady Ministrów z dnia 16 sierpnia 2011 r. w sprawie ustanowienia programu wieloletniego pod nazwą „Ochrona roślin uprawnych z uwzględnieniem bezpieczeństwa żywności oraz ograniczenia strat $\mathrm{w}$ plonach i zagrożeń dla zdrowia ludzi, zwierząt domowych i środowiska". 2011.

Ustawa z dnia 18 grudnia 2003 r. o ochronie roślin. 2004. Dz. U. $2004 \mathrm{nr} 11$, poz. 95 z późn. zm.; tekst jednolity z dnia 15.01.2014 r.

Ustawa z dnia 25 sierpnia 2006 r. o bezpieczeństwie żywności i żywienia. 2010. Dz. U. $2010 \mathrm{nr} 136$ poz. 914, z późn. zm.

Ustawa z dnia z 8 marca 2013 r. o środkach ochrony roślin. 2013. Dz. U. z 2013 poz. 455.

Walorczyk S. 2008. Development of a multi-residue method for the determination of pesticides in cereals and dry animal feed using gas chromatography-tandem quadrupole mass spectrometry II. Improvement and extension to new analytes. Journal of Chromatography A 1208: 202-214.

Walorczyk S., Drożdżyński D. 2011. Development and validation of a routine multiresidue method for determining 140 pesticides in fruits and vegetables by gas chromatography/tandem quadrupole mass spectrometry. Journal of AOAC International 94 (5): $1625-1642$. 